\title{
Энергетика. Автоматика
}

УДК 332.132

Козлов Александр Николаевич

Амурский государственный университет

г. Благовешенск, Россия

E-mail: kozlov1951@yandex.ru

Kozlov Alexander Nikolaevich

Amur State University

Blagoveshchensk, Russia

E-mail: kozlov1951@yandex.ru

Мирошниченко Татьяна Александровна

Амурский государственный университет

г. Благовещенск, Россия

E-mail: tatyanamirosch@mail.ru

Miroshnichenko Tatiana Alexandrovna

Amur State University

Blagoveshchensk, Russia

E-mail: tatyanamirosch@mail.ru

Сидоров Евгений Юрьевич

ООО «Амурские геоинформационные технологии»

г. Благовещенск, Россия

E-mail: amurgit@bk.ru

Sidorov Evgeny Yurievich

LLC «Amur Geoinformation Technologies»

E-mail: amurgit@bk.ru

\section{КАРТОГРАФИЧЕСКАЯ ОЦЕНКА СОВРЕМЕННОГО СОСТОЯНИЯ \\ ТОПЛИВНО-ЭНЕРГЕТИЧЕСКОГО КОМПЛЕКСА АМУРСКОЙ ОБЛАСТИ}

\section{CARTOGRAPHIC ASSESSMENT OF THE CURRENT STATE OF THE FUEL AND ENERGY COMPLEX OF THE AMUR REGION}

Аннотация. Реализация на территории Амурской области крупных проектов в сфере транспорта, газовой и химической промышленности позволит внести коррективы в исторически сложивщийся дисбаланс в размещении генерирующих энергетических мощностей и основных потребителей. В работе представлены картосхемы, наглядно показывающие современное и перспективное состояние электро- и теплоэнергетики Амурской области.

Abstract. The implementation of large projects in the field of transport, gas and chemical industries on the territory of the Amur Region will make it possible to correct the historically formed imbalance in the location of generating power facilities and main consumers. The work presents schematic maps that clearly show the current and future state of the electrical and heat power industry of the Amur region.

Ключевые слова: территориальная структура ТЭК, производство и потребление электроэнергии, картосхема, потери тепла и электроэнергии.

Key words: territorial structure of the fuel and energy complex, production and consumption of electricity, schematic map, losses of heat and electricity.

DOI: 10/22250/jasu.7 
В последние годы избыток электроэнергии, который сформировался в Амурской области за счет ввода крупных ГЭС, становится востребованным. Это происходит благодаря реализации на территории региона инвестиционных проектов в таких отраслях как транспорт, газопереработка, космос. Помимо энергоресурсного фактора, размещение объектов этих отраслей на территории области продиктовано требованиями логистики (например, рядом с местом возведения газоперерабатывющего завода находятся федеральная трасса «Амур», Транссибирская магистраль, река Зея).

Следует отметить, что в Амурской области сформировался дисбаланс в плане размещения энергопроизводственных мощностей, находящихся в основном на севере и юго-востоке области, и потребителей электро- и теплоэнергии, сконцентрированных на ее юге и юго-западе.

Топливно-энергетические ресурсы области позволяют практически полностью обеспечивать собственных потребителей углем, электро- и теплоэнергией, однако по экономическим причинам в область (в основном на север) завозятся угли из Восточной Сибири и Республики Саха (Якутия), а также поставляется электроэнергия с федерального оптового рынка электроэнергии и мощности (ФОРЭМ). Причины этого - в особенностях сетевой энергетической инфраструктуры. Например, узловая подстанция 220/110/35/10 кВ «Тында», через которую осуществляется электроснабжение потребителей северных районов области, получает питание по одной линии 220 кВ от Амурской энергосистемы и по двум линиям 220 кВ - из-за пределов области, от Нерюнгринской ГРЭС, расположенной в Южной Якутии (рис. 1) [8].

Что касается связей с другими регионами, можно отметить следующее: ОЭС Востока и ОЭС Сибири связаны двумя ВЛ 220 кВ, но работают не параллельно и не синхронно. Точки раздела на этих ВЛ устанавливаются оперативно, в зависимости от складывающегося баланса энергообъединений, т.е. линии задействуются по мере необходимости.

С энергосистемами Хабаровского края и Еврейской автономной области (ЕАО) связи поддерживаются за счет: ВЛ 500 кВ Бурейская ГЭС - Хабаровская № 1; ВЛ 500 кВ Бурейская ГЭС - Хабаровская № 2; ВЛ 220 кВ Февральская - Этеркан; ВЛ 220 кВ Архара - Облучье с отпайкой на ПС Тарманчукан/т; ВЛ 220 кВ Ядрин/т - Облучье.

Кроме того, по нескольким линиям осуществляются электроэнергетические поставки в Китай: ВЛ 500 кВ Амурская - Хэйхэ; ВЛ 220 кВ Благовещенская - Айгунь І цепь; ВЛ 220 кВ Благовещенская - Айгунь II цепь; ВЛ 110 кВ Благовещенская - Хэйхэ; ВЛ 110 кВ Сиваки - Шипачжань с отпайкой на ПС Байна.

За последние пять лет объем экспорта электроэнергии в КНР из Амурской области изменялся незначительно, составив в среднем 3,3 млрд кВт·ч. Основная причина заключается в том, что Китай не стремится значительно наращивать импорт электроэнергии из соображений энергетической безопасности и при этом активно развивает собственные энергетические мощности - прирост производства электроэнергии составляет в среднем 5-6\% в год. Поэтому строительство новых энергоемких объектов на территории области в последние годы выглядит привлекательно с любых позиций - рост энергопотребления, рост производства добавленной стоимости, рост занятости, обновление инфраструктуры и в целом структурная перестройка хозяйственного комплекса региона.

Что касается стоимости российских экспортных поставок электроэнергии, то по действующему контракту между «ВЭК» и Государственной электросетевой корпорацией Китая тариф составляет 49 долл. США/МВт·ч.

Если учесть, что среднеотпускной тариф для Дальнего Востока на оптовом рынке электроэнергии в России составил в 2016 г. 679,49 руб./МВт·ч, что равносильно 10,14 долл. США/МВт·ч (по курсу Центробанка в 2016 г.), то следует вывод о достаточно высокой эффективности экспорта электроэнергии в КНР. 


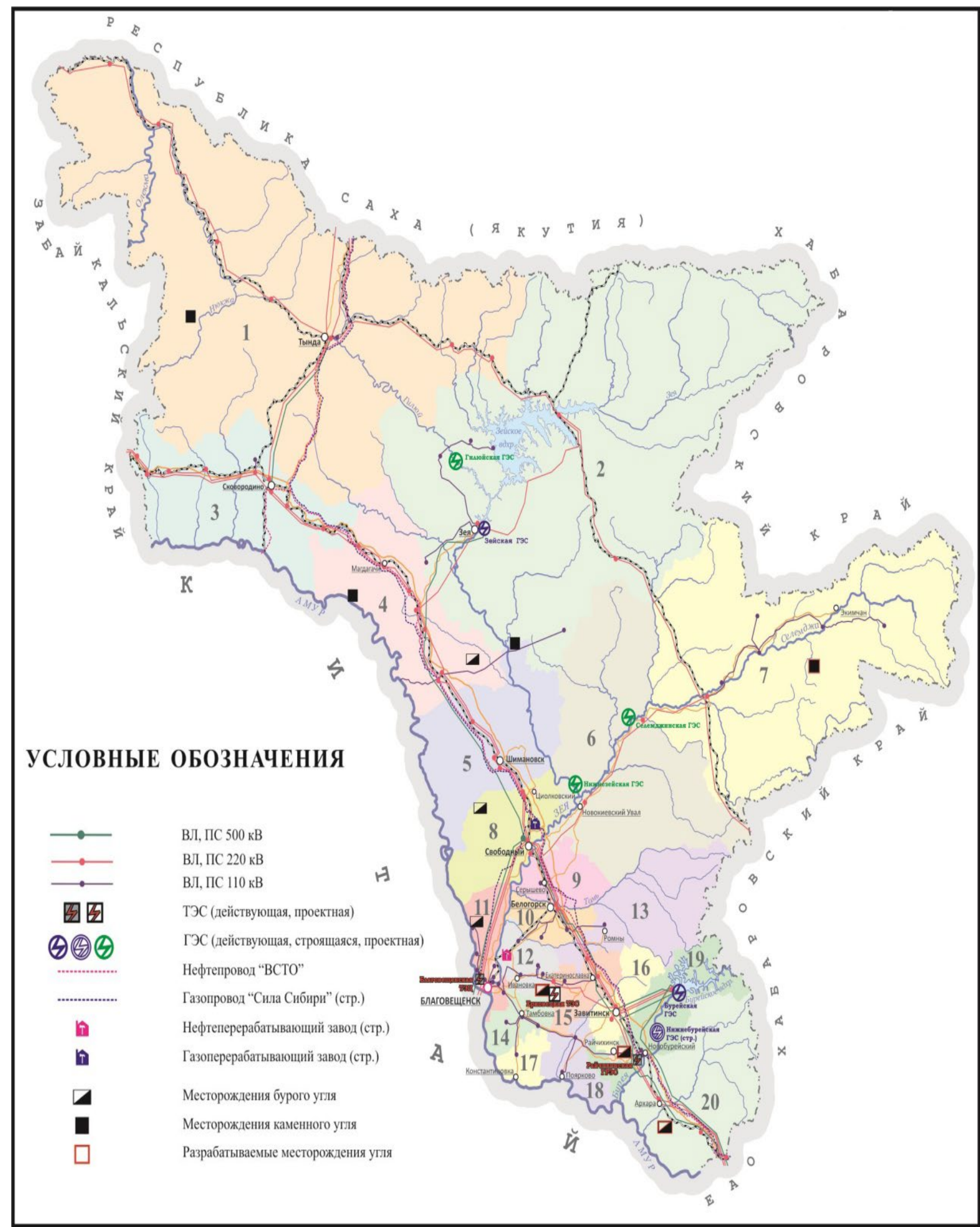

Puc. 1. Территориальная структура топливно-энергетического комплекса Амурской области:

Районы: 1. Тындинский; 2. Зейский; 3. Сковородинский; 4. Магдагачинский; 5. Шимановский; 6. Мазановский; 7. Селемджинский; 8. Свободненский; 9. Серышевский; 10. Белогорский; 11. Благовещенский; 12. Ивановский; 13. Ромненский; 14. Тамбовский; 15. Октябрьский; 16. Завитинский; 17. Константиновский; 18. Михайловский; 19. Бурейский; 20. Архаринский.

В состав энергосистемы Амурской области входят 5 электростанций общей установленной мощностью 5166 МВт, в том числе три гидростанции - 3660 МВт (Зейская ГЭС с установленной 
мощностью 1330 МВт, Бурейская ГЭС - 2010 МВт, Нижне-Бурейская ГЭС - 320 МВт), две тепловые электростанции - 506 МВт (Благовещенская ТЭЦ с установленной мощностью 404 МВт, Райчихинская ГРЭС - 102 МВт). В перспективе рассматриваются варианты строительства в области еще трех ГЭС - Гилюйской, Нижнезейской, Селемджинской, а также одной ТЭС - Ерковецкой. Строительство последней предполагается исключительно в целях расширения экспортных поставок электроэнергии, но до настоящего времени окончательно не определена даже мощность будущей электростанции.

Кроме того, в состав ЭС Амурской области входят сети напряжением 500 - 220 кВ ПАО «ФСК ЕЭС», 110 - 35 кВ АО «ДРСК» и 18 других сетевых организаций. Крупнейшими электросетевыми компаниями на территории области являются филиал АО «ДРСК» «Амурские электрические сети» и филиал ПАО «ФСК ЕЭС» - МЭС Востока.

Сбыт электрической энергии конечным потребителям на территории области осуществляет гарантирующий поставщик - филиал ПАО «ДЭК» - «Амурэнергосбыт» [8]. Существующую сетевую инфраструктуру необходимо совершенствовать и наращивать, так как основная часть электростанций расположена вдали от массовых потребителей электроэнергии: Зейская ГЭС - на севере области, Бурейская ГЭС, Нижне-Бурейская ГЭС, Благовещенская ТЭЦ и Райчихинская ГРЭС - в южных районах. Соответственно, такой вид промышленной деятельности как «производство и распределение электроэнергии, газа и воды» (ПРЭГВ) в четырех населенных пунктах представлен производством электроэнергии (г. Благовещенск, г. Зея, пгт Талакан, пгт Прогресс), а на остальной территории области - распределением (рис. 2) [5, 7, 8].

Что касается структуры электропотребления, следует отметить следующее. В г. Благовещенске большая доля электропотребления приходится на промышленное производство и население. Значительная доля промышленного электропотребления характерна также для таких поселений как г. Райчихинск, пгт Талакан - более $50 \%$ от общего электропотребления (за счет ПРЭГВ), а также для таких городских округов как Белогорск, Зея и пгт Прогресс, пгт Магдагачи и пгт Новобурейский более 25\%. В остальных населенных пунктах доля промышленного электропотребления ниже (рис. 2).

Электропотребление такого вида экономической деятельности как «транспорт и связь» формируется в области в основном за счет электрифицированного железнодорожного транспорта. В этом плане следует выделить г. Тынду, г. Шимановск, г. Свободный, г. Сковородино, г. Завитинск, пгт Магдагачи, г. Циолковский, пгт Архара, пгт Новобурейский.

Практически во всех городских округах и поселках городского типа в электропотреблении очень высока доля населения и жилищно-коммунального хозяйства, это связано с отсутствием крупных промышленных потребителей на территории области. Но в последнее время ситуация меняется.

Согласно [8], в регионе запланировано и уже осуществляется строительство ряда крупных промышленных и других объектов. Некоторые из них частично уже введены в строй, будут увеличивать производство продукции и потребление электроэнергии. Например, космодром «Восточный», золотодобывающие предприятия - Маломырский рудник, Албынский рудник, Покровский рудник (табл. 1 и рис. 2). Объем электропотребления представленных объектов составит около 936 млн кВт·ч [8].

Что касается объектов проектируемых или находящихся в стадии строительства (табл. 2, рис. 2), их перспективное электропотребление составит около 1,5 млрд кВт·ч [8].

Все перечисленные объекты представлены на картосхеме области (рис. 2). Предприятия добывающей промышленности в территориальном плане сконцентрированы в основном на северозападе и северо-востоке области, что в определенной степени выравнивает дисбаланс в размещении энергопроизводства и энергопотребления. Строительство перерабатывающих производств - Амурского газоперерабатывающего завода, Зейского цементного завода, Амурского нефтеперерабатывающего завода - запланировано в южных и центральных муниципальных образованиях. 


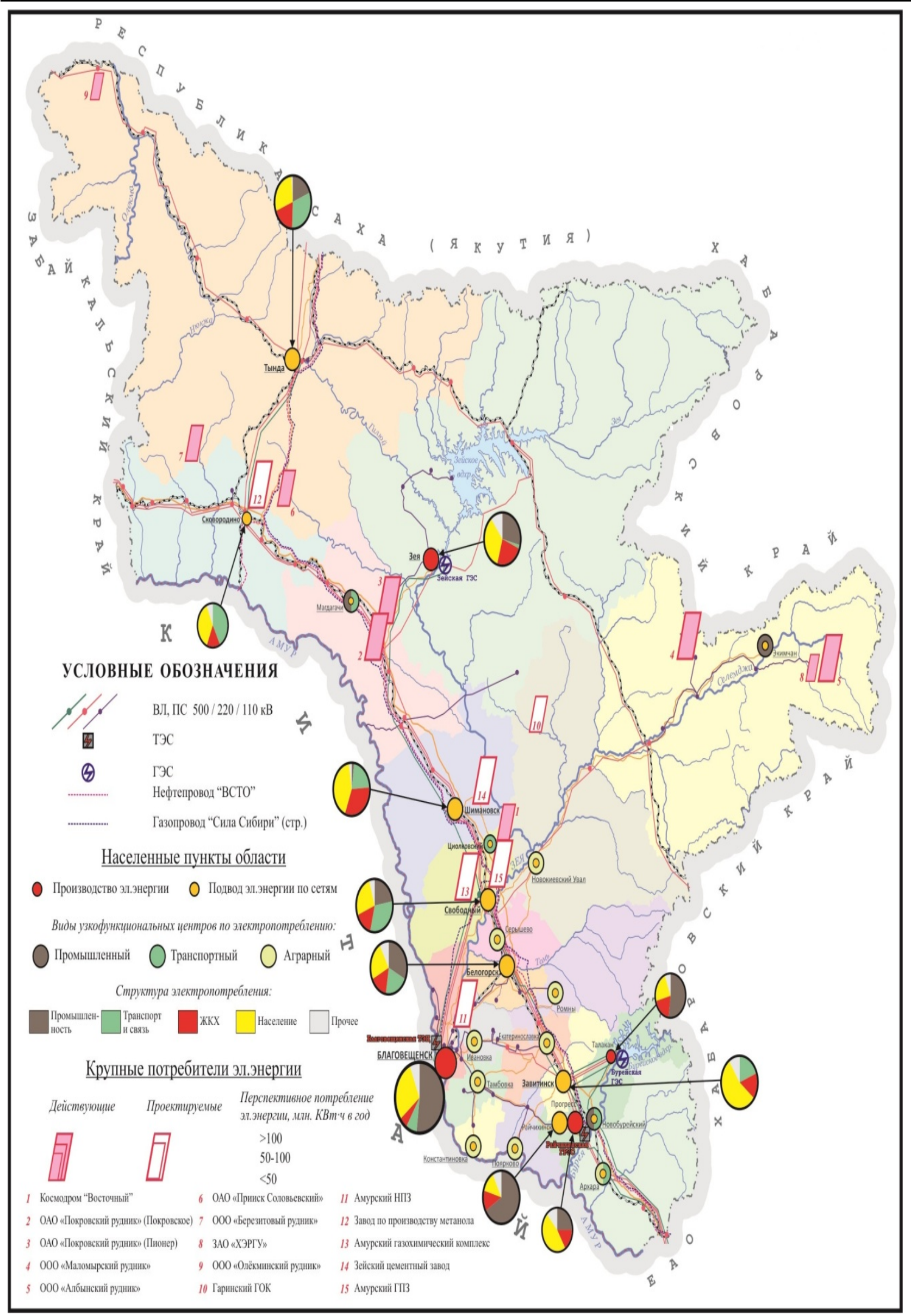

Puc. 2. Звенья ТЭК в территориальной структуре хозяйства Амурской области

(нумерация районов идентична рис. 1). 
Таблица 1

Перечень отдельных крупных потребителей электрической энергии в Амурской области в 2016 г.

\begin{tabular}{|l|c|c|}
\hline \multicolumn{1}{|c|}{ Потребители } & Место расположения & $\begin{array}{c}\text { Потребление, } \\
\text { млн кВт·ч }\end{array}$ \\
\hline Космодром «Восточный» & Свободненский р-н & 75 \\
\hline ОАО «Покровский рудник» (золото) & $\begin{array}{c}\text { месторождение «Покровское», } \\
\text { Магдагачинский р-н }\end{array}$ & 270 \\
\hline ОАО «Покровский рудник» (золото) & $\begin{array}{c}\text { месторождение «Пионер», } \\
\text { Зейский р-н }\end{array}$ & 124,9 \\
\hline ООО «Маломырский рудник» (золото) & $\begin{array}{c}\text { месторождение «Маломыр», } \\
\text { Селемджинский р-н }\end{array}$ & 159,5 \\
\hline ООО «Албынский рудник» (золото) & $\begin{array}{c}\text { месторождение «Албын», } \\
\text { Селемджинский р-н }\end{array}$ & 13,6 \\
\hline $\begin{array}{l}\text { ООО «Олекминский рудник» (черн. метал- } \\
\text { лург.) }\end{array}$ & Тындинский р-н \\
\hline ОАО «Прииск Соловьевский» (золото) & Тындинский р-н & 54,3 \\
\hline ООО «Березитовый рудник» (золото) & Тындинский р-н & 88,2 \\
\hline ЗАО «ХЭРГУ» (золото) & Селемджинский р-н & 17,1 \\
\hline АО «Нижне-Бурейская ГЭС» & Бурейский р-н & 29 \\
\hline Итого & & 936,6 \\
\hline
\end{tabular}

Таблийа 2

Перспективные инвестиционные проекты к 2020 г.

\begin{tabular}{|l|c|c|}
\hline \multicolumn{1}{|c|}{ Потребители } & Место расположения & $\begin{array}{c}\text { Потребление, } \\
\text { млн кВт·ч }\end{array}$ \\
\hline Гаринский ГОК (черн. металлург.) & Мазановский $\mathrm{p}-\mathrm{H}$ & 60 \\
\hline Амурский НПЗ & Ивановский $\mathrm{p}-\mathrm{H}$ & 336 \\
\hline Завод по производству метанола & г. Сковородино & 323 \\
\hline Амурский газохимический комплекс (ГХК) & Свободненский $\mathrm{p}-\mathrm{H}$ & 125,8 \\
\hline Зейский цементный завод & г. Шимановск & 500 \\
\hline Амурский ГПЗ & Свободненский $\mathrm{p}-\mathrm{H}$ & 1464,8 \\
\hline Итого & & \\
\hline
\end{tabular}

Приведенное выше картографическое отображение соотношений производства и потребления электроэнергии по поселениям и районам показывает соотношения основных звеньев территориальной структуры ТЭК с территориальной структурой хозяйства области в целом.

Было проведено сопоставление объемов промышленного производства по видам экономической деятельности в муниципальных образованиях (относительно среднего уровня производства по каждому виду) с уровнем электропотребления в них и с объемом потерь электроэнергии от отпуска по муниципальному району/городскому округу (рис. 3) [6, 7].

В районах с наиболее развитым промышленным производством потери в электросетях, как правило, не превышают 15\%, это связано с тем, что при модернизации старых и строительстве новых промышленных объектов процесс обновления затрагивает и энергетическую инфраструктуру. В то же время в ряде муниципальных образований, где объемы промышленного производства ниже, потери электроэнергии превышают $20 \%$.

Аналогично была рассмотрена ситуация с электропотерями в муниципальных образованиях с преимущественно сельскохозяйственным производством - рис. 4 [6, 7].

В результате выявлено, что в районах, где объемы сельскохозяйственного производства и электропотребления невелики, часто наблюдаются весьма значительные потери электроэнергии. Коэффициент корреляции между этими двумя показателями составил 0,48 , что свидетельствует о некоторой зависимости (мало потребителей, высокие потери, так как нет веских причин оперативно приводить сети в порядок). Исключение составляет Благовещенский район, характеризующийся высоким электропотреблением, не слишком большим сельскохозяйственным производством и невысокими электропотерями - $13 \%$. 


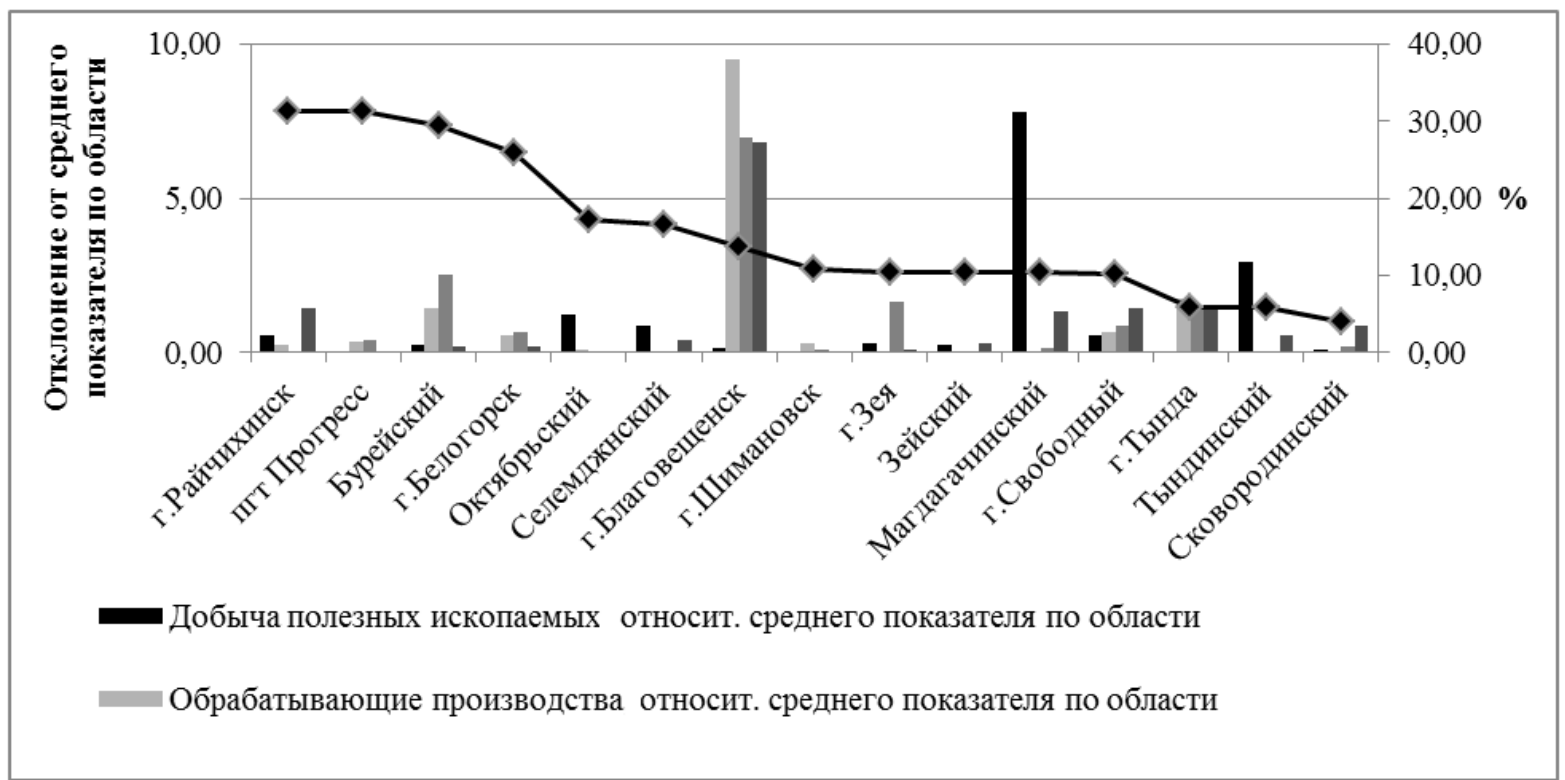

Puc. 3. Соотношение промышленного производства в отдельных муниципальных районах и городских округах Амурской области с уровнем электропотребления и потерь электроэнергии в них в 2014 г.

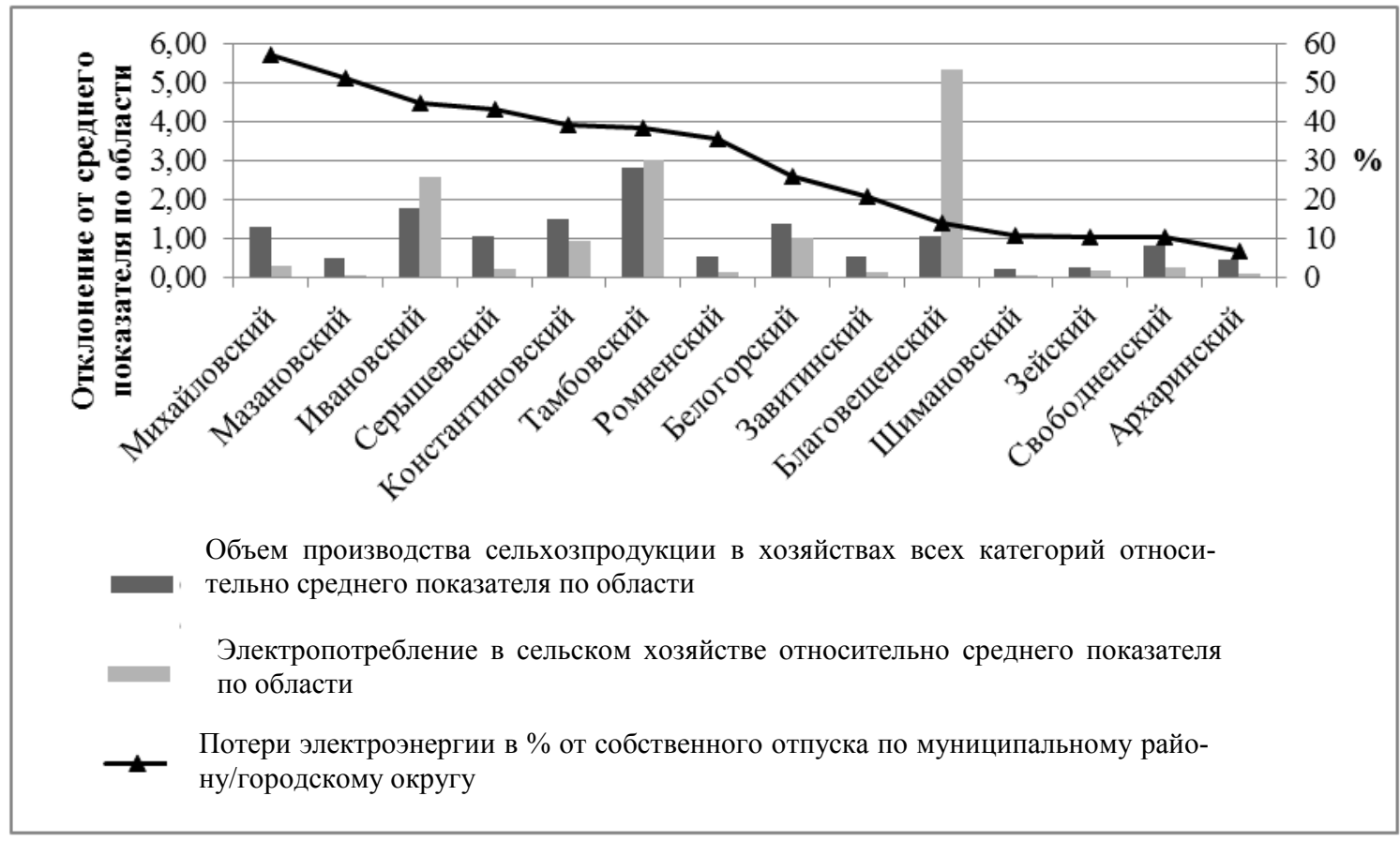

Puc. 4. Сопоставление объемов сельскохозяйственного производства и электропотребления с уровнем потерь электроэнергии по районам области.

Помимо электроэнергетики, следует отдельно представить современное состояние и перспективы развития теплоэнергетики в Амурской области.

Доля угля, добываемого в области, составляет 11\% от объемов добычи по Дальнему Востоку и около $0,87 \%$ от добычи по России в целом (по данным на 2016 г.). Реализуется он преимущественно на территории области [2], так как свыше 95\% разведанных запасов представлено низкокачественными бурыми углями технологических групп Б1 и Б2, которые можно использовать только для сжигания на месте добычи или в брикетированном виде.

Теплоснабжение региона в настоящее время осуществляется от Благовещенской ТЭЦ, Райчихинской ГРЭС а также 876 муниципальных и ведомственных котельных. 
Установленная электрическая мощность Райчихинской ГРЭС составляет 102 МВт, тепловая 228 Гкал/час.

На Благовещенской ТЭЦ с декабря 2015 г. по апрель 2016 г. успешно прошел аттестационные и гарантийные испытания новый энергоблок второй очереди ТЭЦ. В результате установленная электрическая мощность ТЭЦ выросла на 120 МВт и составила 400 МВт, тепловая мощность выросла на 188 Гкал/ч и составила 1005 Гкал/ч. Теперь следует ожидать, что годовой отпуск теплоэнергии увеличится на 730 тыс. Гкал и составит 2854 тыс. Гкал. Топливом для станции станет уголь разреза «Ерковецкий» [4]. Необходимость строительства второй очереди ТЭЦ была продиктована ростом теплопотребления в результате развития промышленного производства и увеличения объемов строительства благоустроенного жилья.

Тем не менее, несмотря на указанные преобразования, в структуре производства тепловой энергии по области основная доля приходится на котельные - 71 \% (рис. 5) [8]. Порядка 5\% от указанной годовой выработки приходится на котельные, оборудованные электрическими котлами. Остальная выработка тепловой энергии - 29\% - производится на ТЭЦ и ГРЭС в ходе комбинированной выработки тепловой и электрической энергии. При этом доля полезного отпуска тепла на ТЭЦ выше, чем на котельных.

Бо́льшая часть котельных - 76,9\% (673) - это котельные малой мощности (до 3 Гкал/час), 19,8\% (174) - котельные мощностью от 3 до 20 Гкал/час и 3,2\% (28) - от 20 до 100 Гкал/час. Источники теплоснабжения с малой мощностью расположены в основном в сельской местности. Фактический коэффициент полезного действия таких котельных составляет 30-58\% вместо 70-80\% по паспорту, что значительно снижает их располагаемую мощность и приводит к существенному (на 30 $40 \%)$ перерасходу топлива. Причина - износ установленного оборудования. Кроме того, это обстоятельство отрицательно сказывается на экологической обстановке. В крупных городах области доля низкоэкономичных котельных несколько ниже и составляет чуть более 50\% [7].

Основным видом топлива для большинства котельных служит бурый уголь местных месторождений - Райчихинского и Ерковецкого (рис. 5).

Потребность области в угле на 96\% покрывается за счет собственной добычи, остальное составляют читинские угли и якутские на севере области. Отказываться от этих поставок нецелесообразно, так как, к примеру, котельные Тынды приспособлены для сжигания только высококачественного якутского угля, и тарифы за теплоэнергию здесь самые низкие в области. Помимо того используется мазут (около 1\%), в основном он сжигается в качестве растопочного топлива и идет на поддержание горения при использовании на ТЭС угля с высокой зольностью. В меньших объёмах на некоторых котельных в качестве первоначального энергоресурса для выработки тепловой энергии применяется дизельное топливо, дрова и древесные материалы.

Протяженность тепловых сетей, принадлежащих муниципальным образованиям области, составляет 1,742 тыс. км; более 500 км из них (около 30\%) нуждается в замене. Около 70\% тепловых сетей отработали нормативный срок эксплуатации - 25 лет [7]. Недопустимым считается 45-процентный износ, а таких тепловых сетей в области насчитывается более 58\%. На уровне 2020 г. практически все сети перейдут в разряд изношенных. Наиболее изношенные сети в Мазановском $77 \%$, Архаринском - 70\%, Свободненском - 54,5\%, Селемджинском - 42\% районах, а также в городах Шимановске - 46,5 \%, Райчихинске - 46 \%. В целом износ тепловых сетей по области составляет более $65 \%$ [7].

В целях исправления сложившейся ситуации на территории области запланирована реконструкция ряда теплоснабжающих объектов с увеличением проектной мощности, а также наращивание теплогенерирующих мощностей в связи со строительством крупных промышленных объектов. 


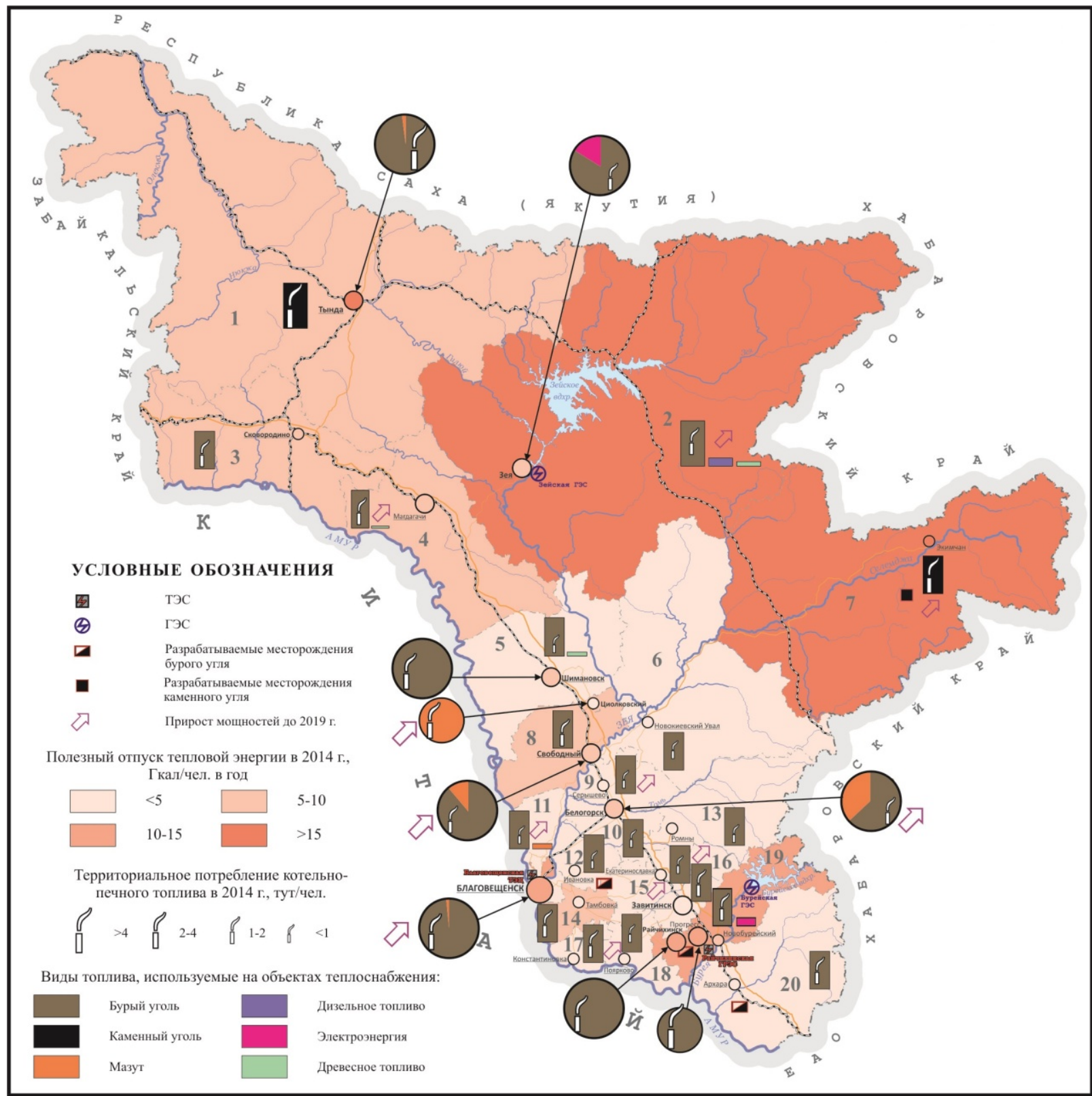

Puc. 5. Территориальная структура теплоснабжения в Амурской области (нумерация районов идентична рис. 1).

Новое строительство и реконструкция запланированы в 11 муниципальных образованиях области. Наибольший прирост мощности ожидается в городских округах Благовещенск, Свободный, Белогорск.

В итоге следует отметить, что, несмотря на заключение долгосрочного контракта на поставку электроэнергии из Амурской области в Китай, в ближайшей перспективе объемы потребностей китайских партнеров остаются под вопросом из-за активного наращивания ими собственных генерирующих мощностей. Роста объема поставок в ближайшие пять лет не планируется. Рост электропотребления с учетом ввода в строй новых энергоемких объектов в Амурской области может быть удовлетворен за счет мощностей имеющихся станций, при этом нынешний объем экспортных поставок будет обеспечен с запасом. Таким образом, строительство новых ГЭС и ТЭС только в целях обеспечения экспорта электроэнергии нецелесообразно. $620 \mathrm{c}$.

1. Амурский статистический ежегодник 2009: Статистический сборник. - Благовещенск: Амурстат, 2009. - 
2. Амурский статистический ежегодник 2017: Статистический сборник. - Благовещенск: Амурстат, 2017. $472 \mathrm{c}$.

3. Ерковецкий угольный разрез ввели в эксплуатацию 30 лет назад / Официальный сайт. - URL: http://www.ruscoal.ru/erkovetskij-razrez-vveli-v-ekspluatatsiyu-30-let-nazad. (дата обращения: 27.08.2016).

4. Началась пуско-наладка электротехнического оборудования 2-й очереди Благовещенской ТЭЦ /РусГидро: Официальный сайт. - URL: http://www.rushydro.ru/press/news/98667.html (дата обращения: 03.06. 2016).

5. Основные положения «Программы строительства новых гидроэнергетических объектов на притоках реки Амур в целях регулирования водосброса в паводковые периоды». - Л.: Ленгидропроект, 2013. - 203 с.

6. Паспорта городов и районов Амур. обл. 2015 / Офиц. сайт территориального органа Федеральной службы государственной статистики по Амурской области: Амурстат. - URL: https://amurstat. gks.ru/statistic (дата обращения 12.08.2016).

7. Программа энергосбережения и повышения энергетической эффективности в Амурской области на период с 2010 по 2014 год: от 30.08.2010 № 471 / Официальный сайт Правительства Амурской области. - URL: http://www.amurobl.ru. (дата обращения: 02.04.2011).

8. Схема и программа развития электроэнергетики Амурской области на период 2015-2019 годов / СанктПетербург, 2015. - 159 c. - URL: https://www.amurobl.ru/pages/ekonomika/ecnomoka-promyshlennoe-proizvodstvo/ toplivno-energeticheskiy-kompleks/skhema-i-programma-razvitiya-elektroenergetiki-amurskoy-oblasti/ skhema-i-programma-razvitiya-elektroenergetiki-amurskoy-oblasti-na-period-2015-2019-godov-/ (дата обращения: 17.10.2018).

УДК 697.31

Артюшевская Екатерина Юрьевна

Амурский государственный университет

г. Благовещенск, Россия

E-mail: kateona2006@yandex.ru

Artyushevskaya Ekaterina Yurievna

Amur State University

Blagoveshchensk, Russia

E-mail: kateona2006@yandex.ru

\section{СПОСОБЫ ПОВЫШЕНИЯ ЭНЕРГОЭФФЕКТИВНОСТИ И ЭКОНОМИИ ТЕПЛОВОЙ ЭНЕРГИИ В ЗДАНИЯХ}

\section{WAYS TO IMPROVE ENERGY EFFICIENCY AND SAVE HEAT IN BUILDINGS}

Аннотация. В статье проведена оценка возможностей экономии тепловой энергии у потребителей и рассмотрены пути повышения энергоэффективности зданий.

Abstract. The article evaluates the possibilities of saving heat energy for consumers and considers ways to improve the energy efficiency of buildings.

Ключевые слова: экономия, энергоэффективность, тепловые сети, тепловая энергия, теплоснабжение, потребитель, здание. building.

Key words: economy, energy efficiency, heat networks, heat energy, heat supply, consumer,

\section{DOI: $10 / 22250 /$ jasu.8}

В современном мире вопрос об энергосбережении является одним из приоритетных. Это связано с тем, что при дефиците основных энергоресурсов стоимость их добычи в разы возрастает. На международной энергетической конференции принято понятие «экономия энергии». Экономия энергии - это эффективное использование энергоресурсов за счет инновационных решений, которые 